Indonesian Journal of Biotechnology, December 2015

Vol. 20, No. 2, pp.133-140

\title{
Elimination of shallot bulb viruses through heat treatment
}

\author{
Margo Sulistio $^{1}$, Endang Sulistyaningsih ${ }^{2}$, Siti Subandiyah ${ }^{2,3^{*}}$
}

\author{
${ }^{1}$ Department of Biotechnology, Graduate School, Universitas Gadjah Mada, Yogyakarta, Indonesia \\ ${ }^{2}$ Faculty of Agriculture, Universitas Gadjah Mada, Yogyakarta, Indonesia \\ ${ }^{3}$ Research Center for Biotechnology, Universitas Gadjah Mada, Yogyakarta, Indonesia
}

\begin{abstract}
Shallot (Allium cepa L. Aggregatum group) is usually cultivated vegetatively. As a result, viruses tend to accumulate within the host plants and spread to healthy plants every crop cycle, reducing yield and bulb quality. There are a very limited number of studies about the elimination of shallot viruses through heat treatment. The objective of this research was to eliminate shallot viruses through heat treatment to produce virus-free plantlets.

The leaves of Biru Lancor with specific visual virus symptoms were detected by Reverse TranscriptionPolymerase Chain Reaction (RT-PCR). Then bulbs of Biru Lancor that were positively infected by viruses were used as materials for heat treatment. The treatments were a control (without treatment), electric treatment at 15 $\mathrm{mA}$ for 10 minutes, heat treatment in an incubator at $37^{\circ} \mathrm{C}$ for 4 weeks, heat treatment in a waterbath at $45^{\circ} \mathrm{C}$ for 60 minutes, and combination of heat treatment in an incubator at $37^{\circ} \mathrm{C}$ for 4 weeks and heat treatment in a waterbath at $45^{\circ} \mathrm{C}$ for 60 minutes. After being subjected to heat treatment, the pseudo stem were cultivated in the MS Medium $+1 \mathrm{mg} / \mathrm{L}$ BAP $+1 \mathrm{mg} / \mathrm{L}$ IBA.Virus detection by RT-PCR was conducted 28 days after planting using samples of leaves from each plantlet.

The results of this research showed that the treatments of electric treatment at $15 \mathrm{~mA}$ for 10 minutes and combination of heat treatment in the incubator at $37^{\circ} \mathrm{C}$ for 4 weeks and heat treatment in the waterbath at $45^{\circ} \mathrm{C}$ for 60 minutes could suppress the incidence of Shallot latent virus (SLV) until 100\%. Heat treatment might have an important role in the degradation of virus particles by boosting Virus-Induced Gene Silencing (VIGS) as plant responses to virus infection.
\end{abstract}

Keywords: Shallot, Shallot latent virus, heat treatment

\section{Introduction}

Shallot (Allium cepa L. Aggregatum group) is one of the important horticulture comodities used as a spice in daily consumption. Shallots are vegetatively propagated and usually bring diseases caused by fungi, bacteria and, mainly, viruses. Viruses tend to accumulate within a host and spread to healthy plants in every crop cycle, reducing yield and bulb quality. The major viruses

\section{*Corresponding author:}

Siti Subandiyah

Department of Agriculture, Universitas Gadjah Mada, Jl. Flora Bulaksumur Sleman 55281, Yogyakarta, Indonesia

Email: sitisubandiyah@ugm.ac.id infecting shallots are Onion yellow dwarfvirus (OYDV) and Shallot yellow stripe virus (SYSV), which are classified in genus Potyvirus, and Shallot latent virus (SLV) which is classified in genus Carlavirus (van Dijk, 1993; Barg et al., 1994).

The frequency of infection has been reported to be around $39-100 \%$ for OYDV and SYSV in 13 shallot cultivars in Central Java and West Java (Gunaeni et al., 2011). Other occurences showed that $60 \%$ and $53.3 \%$ of shallot Java variety and Brebes variety, respectively, are infected bySYSV (Kurniawan and Suastika, 2013). In Yogyakarta, 78\% and $60 \%$ of shallots are infected by SLV in the dry and wet seasons, respectively; $62 \%$ and $46 \%$ 
of shallots are infected by OYDV and SYSV in the dry and wet seasons, respectively; and $2 \%$ of shallots are infected by Allexivirus in the dry season (Swari, 2016).

The production and maintenance of virus-free planting materials are urgently needed to control viral diseases (Bhojwani and Razdan, 1996). To date, the number of studies on the elimination of shallot viruses through heat treatment is very limited. The objective of this research was to eliminate shallot viruses through heat treatment to produce virus-free plantlets.

\section{Materials and Methods \\ Sample Preparation}

Specific virus symptoms, such as mosaic, chlorosis, yellow stripe, and abnormal leaf of the shallot (Biru Lancor cultivar) were observed in Kretek, Bantul, Yogyakarta. True Shallot Seed (TSS) of G1 Tuktuk cultivar was used as the control. The leaves of plants with specific virus symptoms were cut off 18 days after planting and then stored at $-20^{\circ} \mathrm{C}$. Bulbs from plants with specific virus symptoms were harvested 58 days after planting. The bulbs were dried under sunlight and then stored for one month to break the dormancy.

\section{Extraction of RNA and cDNA Synthesis (RT-PCR)}

Total RNA was extracted from 100 mg composite leaves of shallot using the Plant Virus RNA Extraction Kit (Geneaid) according to the manufacturer's instructions. cDNA Synthesis (RT-PCR) was performed using the RevertAid First Strand cDNA Synthesis Kit (Thermo Scientific). The RTPCR was done in a $20 \mathrm{ml}$ volume solution containing: $4 \mu \mathrm{L}$ 5X Reaction Buffer, $2 \mu \mathrm{L}$ $10 \mathrm{mM}$ dNTP Mix, $1 \mu \mathrm{L}$ Poty1 primer, $1 \mu \mathrm{L}$ RiboLock RNAse Inhibitor, $1 \mu \mathrm{L}$ RevertAid M-MuLV Reverse Transcriptase, $10 \mu \mathrm{L}$ nuclease-free water, and $1 \mu \mathrm{L}$ RNA template. The cycling profile consisted of $65^{\circ} \mathrm{C}(5$ minutes), $42^{\circ} \mathrm{C}$ (60 minutes), $70^{\circ} \mathrm{C}$ (5 minutes), and $4^{\circ} \mathrm{C}(\infty)$.

\section{DNA Amplification (PCR)}

The virus cDNA resulting from RT-PCR was then multiplied by PCR (Polymerase Chain Reaction). The PCR was done in a $20 \mathrm{ml}$ volume solution containing: $12 \mu \mathrm{L}$ Kapa2G Fast Ready Mix PCR Kit (Thermo Scientific), $4 \mu \mathrm{L}$ nuclease-free water, $1 \mu \mathrm{L}$ Poty1 reverse primer $10 \mu \mathrm{M}, 1 \mu \mathrm{L}$ pCV3t/ AlcarF/U341 forward primer $10 \mu \mathrm{M}$, and 1 $\mu \mathrm{L}$ cDNA template. Primer set: Poty1(IDT)/ pGV3t (Sigma) (5'-GGA TTC CGG GTT TTT TTT TTT TTT TTT V-3' (Gibbs and MacKenzie, 1997) and 5'-TGG NCN TGC TAC CAC AAN GG-3' (Chen et al., 2004)); Poty1(IDT)/AlcarF (Sigma) (5'-GGA TTC CGG GTT TTT TTT TTT TTT TTT V-3' (Gibbs and MacKenzie, 1997) and 5'-TGC TGC YTT TGA TAC YTT CGA T-3') (Gambley, 2012)); Poty1 (IDT)/U341 (Sigma) (5'-GGA TTC CGG GTT TTT TTT TTT TTT TTT V-3' (Gibbs and MacKenzie, 1997) and 5'-CCG GAA TTC ATG RTI TGG TGY ATI GAI AAY GG-3' (Langeveld et al., 1991)) were used for Allexivirus, Carlavirus and Potyvirus detection, respectively. The cycling profile consisted of $3 \mathrm{~min}$ initial denaturation at $94^{\circ} \mathrm{C}$, followed by 30 cycles of denaturation at $94^{\circ} \mathrm{C}$ for $45 \mathrm{~s}$, annealing at $56^{\circ} \mathrm{C}$ for $60 \mathrm{~s}$, extension at $72^{\circ} \mathrm{C}$ for $90 \mathrm{~s}$, and final extension at $72^{\circ} \mathrm{C}$ for $6 \mathrm{~min}$. PCR products were separated on electrophoresis $1.5 \%$ agarose gels in TBE (Tris-Borate-EDTA) buffer $1 x$ and then stained with ethidium bromide and visualized in a UV transilluminator.

\section{Heat Treatment followed by Pseudo Stem Culture}

Twenty bulbs of the Biru Lancor cultivar were positively infected by Carlavirus, confirmed by PCR, dried under sunlight, and stored for 30 days. Furthermore, the bulbs were washed by water containing detergent and rinsed 3 times with tap water. The outer sheath of each bulb was peeled and the total sample divided into 5 groups (with 4 replications): (A) control (without treatment), (B) electric treatment at $15 \mathrm{~mA}$ for 10 minutes, (C) heat treatment in an incubator at $37^{\circ} \mathrm{C}$ for 
4 weeks, (D) heat treatment in a waterbath at $45^{\circ} \mathrm{C}$ for 60 minutes and (E) combination of heat treatment in an incubator at $37^{\circ} \mathrm{C}$ for 4 weeks and heat treatment in a waterbath at $45^{\circ} \mathrm{C}$ for 60 minutes.

After being subjected to heat treatment, the bulbs were sterilized in a laminar air flow with the following steps: bulbs were dipped into $70 \%$ alcohol and then flamed for 5 seconds; bulbs were soaked in clorox $(5.25 \%)+1$ drop of tween 20 for 20 minutes; bulbs were shaken with sterile distilled water three times for 5, 3 , and 1 minute, respectively; bulbs placed in a sterile petri dish and then peeled sheath by sheath using a pair of tweezers and a sterile scalpel until the pseudo stem was found $( \pm 5$ $\mathrm{mm})$. Pseudo stem was planted in the medium $(4,43 \mathrm{~g} / \mathrm{L} \mathrm{MS}$ medium $+30 \mathrm{~g} / \mathrm{L}$ sucrose $+7 \mathrm{~g} / \mathrm{L}$ agar $+1 \mathrm{mg} / \mathrm{L} \mathrm{BAP}+1 \mathrm{mg} / \mathrm{L} \mathrm{IBA}+0,5 \mathrm{~mL} / \mathrm{L}$ $\mathrm{PPM})$ and then stored in incubation room $\left(25^{\circ} \mathrm{C}\right.$ and 3000 lux lighting).

Twenty-eight days after planting, 100 $\mathrm{mg}$ of composite leaves from each group of plantlet was cut off and then virus detection was performed using RT-PCR according to the protocol as mention before.

\section{Results and Discussion Sample Preparation}

The first step in this research was to detect visual virus symptoms in a shallot farm. The detection was expected to find a positive virus infection, after which the bulbs would be used as a source of plant material for virus elimination treatment. Visual virus symptoms in the infected shallot plants, such as yellow mosaic and vertical yellow stripe which is characterized by either continuous or broken lines (Gunaeni et al., 2011). These symptoms was found in the infected shallot plants including infection by OYDV, SYSV and SLV (Bos et al., 1978; Duriat, 1990; Van Dijk, 1993; Van Dijk, 1994; Barg et al., 1994; Arisuryanti et al., 2008, Gunaeni et al., 2011).

Based on the result of the field observation in Kretek, Bantul, Yogyakarta, visual virus symptoms were found as described in Figure 1.

According to these symptoms, the shallots were used to detect and confirm the virus infection by RT-PCR.

\section{Virus Detection using RT-PCR}

Virus detection using RT-PCR was performed on three samples of shallot leaves with visual virus symptoms. The results showed that sample number 5 was positively infected by Carlavirus (SLV) (Figure 2). A specific band for Carlavirus (SLV) was successfully amplified using a
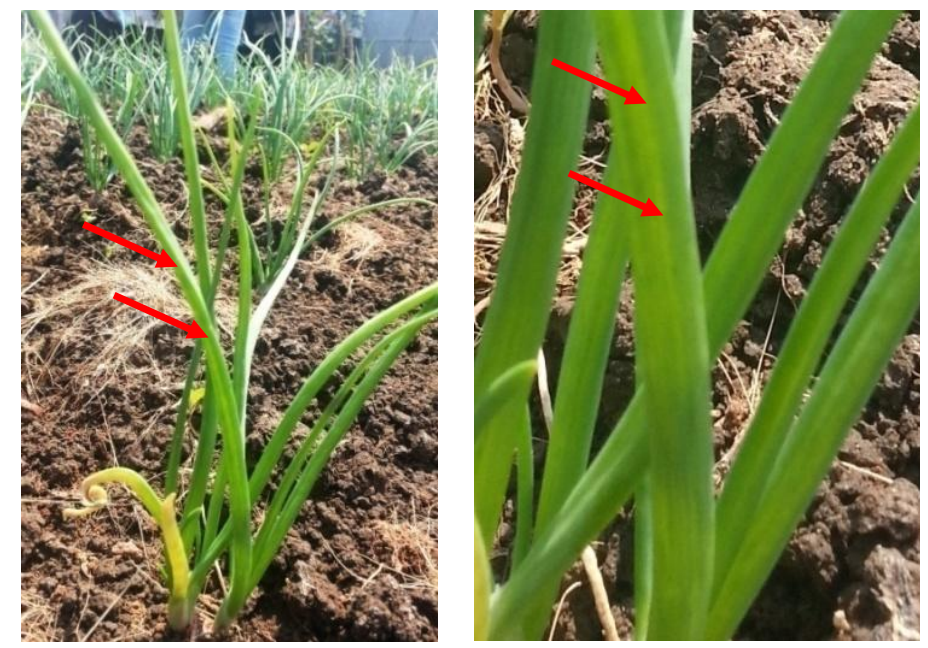

Figure 1. Visual virus symptoms such as yellow mosaic and vertical yellow stripe in the shallot plants in Kretek, Bantul, Yogyakarta (red arrows). 
pair of universal primers for Carlavirus (SLV), namely AlcarF forward primer and Poty1 reverse primer. Meanwhile, Potyvirus and Allexivirus were not successfully amplified in all samples (Figure 3), indicating that all samples were free of Potyvirus and Allexivirus. Based on these results, sample number 5 was used as the material for the heat treatment.

SLV, belonging to genus Carlavirus and family Betaflexiviridae, reportedly infected a wide range of Allium (Bos et al., 1978). The particle of SLV is straight to slightly curved and $650 \mathrm{~nm}$ long. In Bantul, the infection of Carlavirus was higher than Potyvirus in both the dry and wet seasons. The frequency of infection of Carlavirus and Potyvirus in the wet season was $78 \%$ and $62 \%$, respectively. These were higher than the frequency of infection

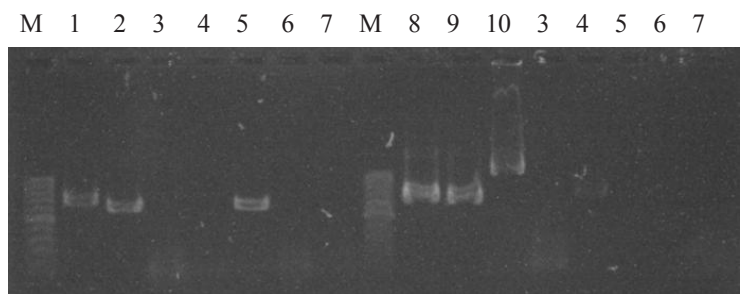

Figure 2. Gel-electrophoresis analysis of PCR products obtained from leaves extract of Biru Lancor with visual virus symptoms using universal primer for Carlavirus and Potyvirus. M, 100 bp DNA Ladder; 1-2, positive control of GCLV and SLV; 3-5, sample; 6-7, negative control True Shallot Seed (TSS) of G1 Tuktuk cultivated in the green house and cultivated in the field; 8-10, positive control of OYDV, SYSV, and LYSV.

$\begin{array}{lllllllllll}M & 11 & 12 & 13 & 14 & 15 & 3 & 4 & 5 & 6 & M\end{array}$

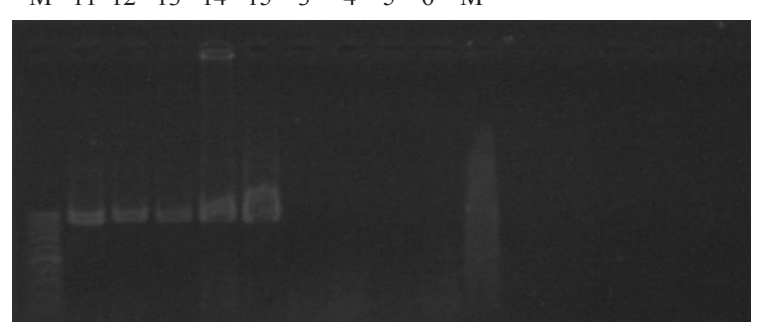

Figure 3. Gel-electrophoresis analysis of PCR products obtained from leaves extract of Biru Lancor var with visual virus symptoms using universal primer for Allexivirus. M, 100 bp DNA Ladder; 3-5, sample; 6, negative control True Shallot Seed (TSS) of G1 Tuktuk cultivated in the green house; 11-15, positive control of GVA, GVB, GVC, GVX, and ShVX. of Carlavirus and Potyvirus in the dry season, $60 \%$ and $46 \%$, respectively (Swari, 2016). In addition, Biru variety was reported to be most tolerant to virus infection among others (Crok variety, Tiron variety and Bauji variety). Infected shallot seeds were suspected to be a main source of Carlavirus infection in shallots in Bantul because nonpersistent transmission through aphid was less efficient than Potyvirus. Meanwhile, weeds have not contributed to the epidemiology of Carlavirus (van Dijk, 1993).

\section{Effects of Heat Treatment on the Plantlet Growth}

Figure 4 shows the mean of leaf number, shoot number, shoot length, and root number of shallot plantlets 4 and 8 weeks after planting (WAP).

In $4 \mathrm{WAP}$, plantlets from the control showed the highest mean leaf number. A tendency of decreasing leaf numbers was found in all of the plantlets subjected to heat treatment. Meanwhile, in $8 \mathrm{WAP}$, the mean leaf number was highest in plantlets subjected to the combination of heat treatment at $37^{\circ} \mathrm{C}$ for 4 weeks and $45^{\circ} \mathrm{C}$ for 60 minutes. This value was significant in statistical difference compared with the other three treatments but not significant in statistical difference compared with the control. The mean of shoot number was highest in plantlets subjected to the heat treatment at $37^{\circ} \mathrm{C}$ for 4 weeks and $45^{\circ} \mathrm{C}$ for 60 minutes both in 4 and 8 WAP. Nevertheless, the mean of shoot number in all treatments was not significant in statistical difference.

In $4 \mathrm{WAP}$, the mean shoot length in plantlets subjected to the heat treatment at $37^{\circ} \mathrm{C}$ for 4 weeks and $45^{\circ} \mathrm{C}$ for 60 minutes showed the highest value. However, the mean shoot length was not significant in statistical difference between treatments. In $8 \mathrm{WAP}$, the highest mean shoot length was $9.75 \mathrm{~cm}$ in the plantlets subjected to heat treatment at $37^{\circ} \mathrm{C}$ for 4 weeks and $45^{\circ} \mathrm{C}$ for 60 minutes. This value was significant in statistical difference compared with three other treatments, but not significant in 


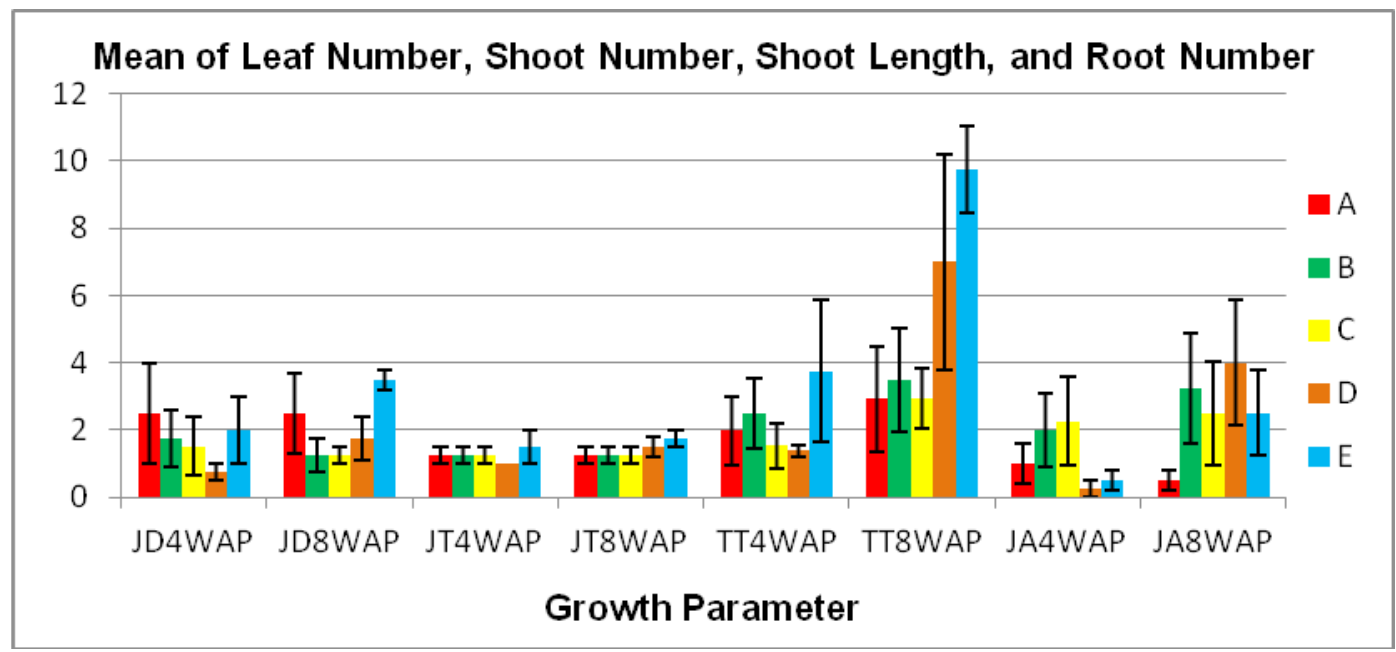

Figure 4. Mean of leaf number, shoot number, shoot length, and root number of shallot plantlets at 4 and 8 WAP. JD: leaf number, JT: shoot number, TT: shoot length, JA: root number. (A) control, (B) electric treatment at $15 \mathrm{~mA}$ for 10 minutes, (C) heat treatment in an incubator at $37^{\circ} \mathrm{C}$ for 4 weeks, (D) heat treatment in a waterbath at $45^{\circ} \mathrm{C}$ for 60 minutes and (E) combination of $\mathrm{C}$ and $\mathrm{D}$

statistical difference compared with the heat treatment at $45^{\circ} \mathrm{C}$ for 60 minutes.

In $4 \mathrm{WAP}$, the mean of root number of plantlets subjected to the electric treatment at $15 \mathrm{~mA}$ for 10 minutes and heat treatment at $37^{\circ} \mathrm{C}$ for 4 weeks showed a higher value than the mean value of the control. Conversely, the mean of root number of plantlets subjected to the heat treatment at $45^{\circ} \mathrm{C}$ for 60 minutes and combination of heat treatment at $37^{\circ} \mathrm{C}$ for 4 weeks and $45^{\circ} \mathrm{C}$ for 60 minutes showed a lower value than the mean value of the control. Meanwhile, in 8 WAP, the mean value of all treatments was higher than the mean value of the control, and they were significant in statistical difference compared with the control.

In general, the growth of the plantlets at 4 WAP was not better than the growth of the plantlets at $8 \mathrm{WAP}$. It was assumed that the heat treatment influenced metabolism and plant growth. It takes more time for growth performance to return after heat treatment. Plants are exposed to heat treatment, virus infection, wounding, biotic or abiotic stress, or parasite attack that are related to changes of $\mathrm{pH}$, increase of RNase, increase of polyphenoloxidase (PPO). These changes affect their metabolism and plant growth (Dove, 1976; Goodman et al., 1976 cit. Johnstone and Wade, 1974).

The growth at 8 WAP of shallot plantlets subjected to heat treatment at $45^{\circ} \mathrm{C}$ for 60 minutes and combination of heat treatment at $37^{\circ} \mathrm{C}$ for 4 weeks and $45^{\circ} \mathrm{C}$ for 60 minutes was better than the other treatments. This indicates that certain temperatures of heat treatment would restore the growth performance of a plant that is infected by a virus. The recovery of the plant growth suggests that the number of virus particles was decreased or eliminated. Therefore, explants are optimally able to absorb nutrients from the media and maximize metabolic processes to synthesize the elements needed for vegetative growth (Styer and Chin, 1983).

\section{Effects of Heat Treatment on Virus Incidence}

The results of virus detection from composite leaves of shallot plantlets using RT-PCR showed that the plantlets that were subjected to electric treatment at $15 \mathrm{~mA}$ for 10 minutes and combination of heat treatment at $37^{\circ} \mathrm{C}$ for 4 weeks and $45^{\circ} \mathrm{C}$ for 60 minutes were free of SLV. Figure 5 shows there were no bands amplified from the two treatments mentioned above. Meanwhile, the specific 
band of SLV was successfully amplified from the control, heat treatment at $37^{\circ} \mathrm{C}$ for 4 weeks, and heat treatment at $45^{\circ} \mathrm{C}$ for 60 minutes. This indicates that the composite leaves of shallot plantlets in this treatments still contained particles of SLV.

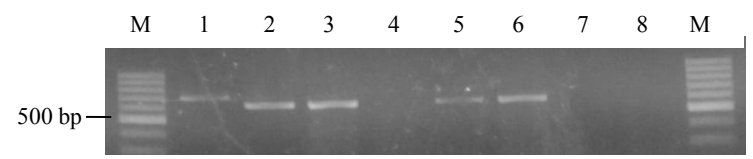

Figure 5. Gel-electrophoresis analysis of PCR products obtained from composite leaves extract of Biru Lancor plantlets after heat treatment followed by pseudo stem culture, using universal primer for Carlavirus. M, $100 \mathrm{bp}$ DNA Ladder; 1-2, positive control of GCLV dan SLV; 3-7, samples with A, B, C, D, E treatments; 8, negative control (True Shallot Seed (TSS) of G1 Tuktuk).

The virus detection was continued during each replication of the treatment to confirm the presence of virus particles in each replication. Figure 6 shows that there was a specific band of SLV amplified using a pair of universal primers for Carlavirus in each replication of the control. This indicates that each plantlet in the control still contained particles of SLV.

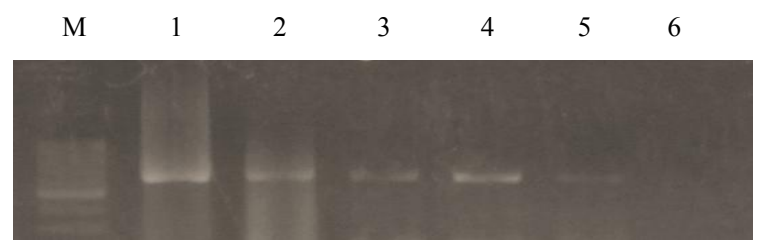

Figure 6. Gel-electrophoresis analysis of PCR products obtained from leaves extract of Biru Lancor plantlets without heat treatment followed by pseudo stem culture, using universal primer for Carlavirus. M, 100 bp DNA Ladder; 1 , positive control of SLV; 2-5, four replications of samples without heat treatment; 6 , negative control (True Shallot Seed (TSS) of G1 Tuktuk).

Figure 7 shows that there were no bands amplified using a pair of universal primers for Carlavirus in each replication of plantlets subjected to electric treatment at $15 \mathrm{~mA}$ for 10 minutes and combination of heat treatment at $37^{\circ} \mathrm{C}$ for 4 weeks and $45^{\circ} \mathrm{C}$ for 60 minutes. This indicates that each plantlet in these treatments was free of SLV.

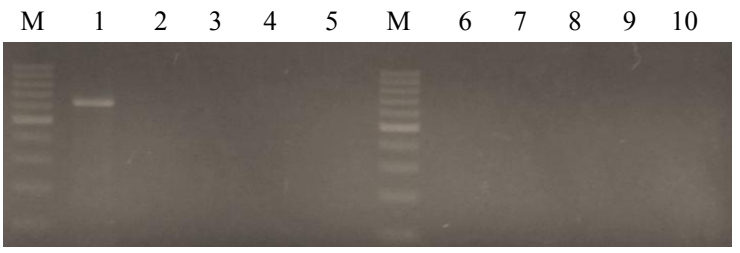

Figure 7. Gel-electrophoresis analysis of PCR products obtained from leaves extract of Biru Lancor plantlets after electric treatment or heat treatment followed by pseudo stem culture, using universal primer for Carlavirus. M, 100 bp DNA Ladder; 1, positive control of SLV; 2-5, four replication of samples after electric treatment at $15 \mathrm{~mA}, 10^{\prime} ; 6-9$, four replications of samples after combination of heat treatment at $37^{\circ} \mathrm{C}, 4$ weeks and $45^{\circ} \mathrm{C}, 60^{\prime} ; 10$, negative control (True Shallot Seed (TSS) of G1 Tuktuk).

Figure 8 shows that there were specific bands of SLV amplified using a pair of universal primers for Carlavirus in each replication of plantlets subjected to heat treatment at $37^{\circ} \mathrm{C}$ for 4 weeks and heat treatment at $45^{\circ} \mathrm{C}$ for 60 minutes. This indicates that each plantlet in these treatments are still contained particles of SLV.

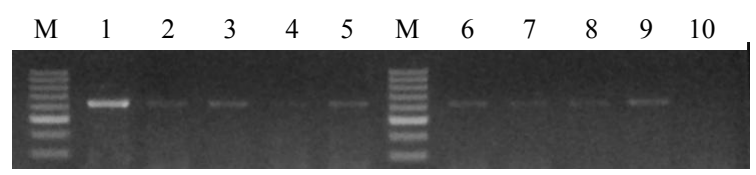

Figure 8. Gel-electrophoresis analysis of PCR products obtained from leaves extract of Biru Lancor plantlets after heat treatment followed by pseudo stem culture, using universal primer for Carlavirus. M, 100 bp DNA Ladder; 1, positive control of SLV; 2-5, four replications of samples after heat treatment at $37^{\circ} \mathrm{C}, 4$ weeks, $10^{\prime}$; $6-9$, four replications of samples after heat treatment at $45^{\circ} \mathrm{C}, 60^{\prime} ; 10$, negative control (True Shallot Seed (TSS) of G1 Tuktuk).

Table 1 shows the virus incidence in shallot plantlets subjected to the heat treatment. The virus incidence of shallot plantlets from the control, heat treatment at $37^{\circ} \mathrm{C}$ for 4 weeks, and heat treatment at $45^{\circ} \mathrm{C}$ for 60 minutes reached $100 \%$. Conversely, both the electric treatment at $15 \mathrm{~mA}$ for 10 minutes and combination of heat treatment at $37^{\circ} \mathrm{C}$ for 4 weeks and $45^{\circ} \mathrm{C}$ for 60 minutes could suppress virus incidence until 100\%. 
Table 1. Virus incidence in shallot plantlets subjected to heat treatment.

\begin{tabular}{ll}
\hline \multicolumn{1}{c}{ Heat treatment } & \multicolumn{1}{c}{\begin{tabular}{c}
\multicolumn{1}{c}{ Virus } \\
Incidence ${ }^{*}(\%)$
\end{tabular}} \\
$\mathrm{A}(\mathrm{Control})$ & $4 / 4(100)$ \\
$\mathrm{B}(15 \mathrm{~mA} ; 10 \mathrm{~min})$ & $0 / 4(0)$ \\
$\mathrm{C}\left(37^{\circ} \mathrm{C} ; 4\right.$ weeks $)$ & $4 / 4(100)$ \\
$\mathrm{D}\left(45^{\circ} \mathrm{C} ; 60 \mathrm{~min}\right)$ & $4 / 4(100)$ \\
$\mathrm{E}\left(37^{\circ} \mathrm{C} ; 4\right.$ weeks and $\left.45^{\circ} \mathrm{C} ; 60 \mathrm{~min}\right)$ & $0 / 4(0)$ \\
\hline
\end{tabular}

* Virus Incidence, ratio of the number of positively infected samples to the total of samples subjected to virus detection.

Certain viruses can be more active at high temperatures whereas other types of viruses are more virulent at lower temperatures. The combination of heat treatment and tissue culture has the potential to suppress some virus infections in certain times and temperatures (Bos, 1983). Converse and Tanne (1984) reported that several viruses decreased their multiplication at $35-43^{\circ} \mathrm{C}$ during a certain time. Heat treatment in an incubator under long day conditions at $38-40^{\circ} \mathrm{C}$ for 3 weeks followed by meristem culture can suppress the infections of Chrysanthemum virus-B (CVB) until 100\% in chrysanthemum plantlets (Budiarto et al., 2008). Garlic shoot tip culture associated with dry heat treatment (cloves exposed to $37^{\circ} \mathrm{C}$ for 35 days) were essential for recovering virus-free plants of the Amarante cultivar. In this condition, $70 \%$ of the explants developed in vitro and produced plants (Torres et al., 2000). Meristem culture of potato using explants $100 \mu \mathrm{m}$ in length combined with thermotherapy at approximately $37 \pm 1^{\circ} \mathrm{C}$ for 40 days produced a high rate of virus-free plants, $81 \%$ in the Binella cultivar and $75 \%$ in the Burren cultivar (Almaarii et al., 2012). Subjecting a shallot bulb to heat treatment at $45^{\circ} \mathrm{C}$ for 30 minutes followed by meristem culture could suppress the incidence of Carlavirus until 100\% (Wulandari, 2016).

The results of this research showed that the treatments of electric treatment at $15 \mathrm{~mA}$ for 10 minutes and combination of heat treatment in an incubator at $37^{\circ} \mathrm{C}$ for 4 weeks and heat treatment in a waterbath at $45^{\circ} \mathrm{C}$ for 60 minutes could suppress the incidence of SLV until $100 \%$. The heat treatment might have an important role in the degradation of the virus particle by inducing Virus-Induced Gene Silencing (VIGS) as the plant responds to virus infection. The concentration of RNase and polyphenoloxidase increased in heat-treated tissues; conversely, the $\mathrm{pH}$ decreased and this may aid virus inactivation (Johnstone and Wade, 1974).

dsRNA produced during the process of ssRNA virus replication could constitute a potent trigger of VIGS. VIGS mechanisms consist of three sequential steps: dsRNA processing into 21-23nt RNA (short interfering RNA, siRNA) by Dicer-like dsRNase, incorporation of siRNA into the RNA-induced Silencing Complex (RISC complex), and RISC-mediated ssRNA degradation (Voinnet, 2001). Thus, an increase of RNase in heat-treated tissues may increase dsRNA processing into siRNA and therefore increase the degradation of ssRNA.

\section{Conclusion}

The different temperatures of heat treatment investigated considerably improved the elimination of SLV from in vitro shoots of shallot. The best treatment was a combination of heat treatment at $37^{\circ} \mathrm{C}$ for 4 weeks and $45^{\circ} \mathrm{C}$ for 60 minutes. Heat treatment is technically simple, lower cost, and applicable for eliminating viruses in shallots. The technique developed in this study can be useful for the production of shallot virus-free plantlets.

\section{Acknowledgments}

The authors are thankful to the Australian Center for International Agricultural Research (ACIAR) for their funding of this research.

\section{References}

Almaarri, K., Massa, R., and Albiski, F. 2012. Evaluation of some therapies and meristem culture to eliminate Potato $Y$ potyvirus from infected potato plants. Plant Biotechnology 29: 237-243. 
Arisuryanti, T., Daryono, B. S., Hartono, S., dan A.A.G.R Swastika. 2008. Observasi dan identifikasi virus yang menginfeksi bawang merah di Jawa. Jurnal Perlindungan Tanaman Indonesia 14(2): 55-62.

Barg, E., Lesemann, D.E., Vetten, H.J., and Green, S.K. 1994. Identification, partial characterization and distribution of viruses infecting Allium crops in south and southeast Asia. Acta Horticultura 358:251-258.

Bhojwani, S.S. and Razdan, M.K. 1996. Plant Tissue Culture: Theory and Practice, Revised Edition. Nedherland: Elsevier.

Bos, L., Huttinga, H. and D.Z. Maat. 1978. Shallot latent virus, a new carlavirus. Neth. J. Plant Path. 84: 227-237.

Bos. 1983. Viruses and virus diseases of Allium species. Acta Hortic. 127: 11-29.

Budiarto K, Sulyo, Y., Rahardjo, I.B., and Pramanik, D. 2008. Pengaruh durasi pemanasan terhadap keberadaan Chrysanthemum virus- $B$ pada tiga varietas krisan terinfeksi. J. Hort. 18(2):185-192.

Chen, J., Zheng, H. Y., Antoniw, J. F., Adams, M. J., Chen, J., and Lin, L. 2004. Detection and classification of Allexiviruses from garlic in China. Arch. Virol. 149:435-445.

Converse, R.H. and Tanne, E. 1984. Heat therapy and stolon apex culture to eliminate Mild yellow-edge virus from Hood stawberry. Phytopathology 74: 1315-1316.

Dove, L.D. 1967. Ribonuclease activity of stressed tomato leaflets. Plant Physiol. 42: 1176-8.

Duriat, A.S. and Sukarna, E. 1990. Deteksi penyakit virus pada klon bawang merah. Bull. Penel. Hort. 8(1): 146-153.

Gambley, C.F., Thomas, J.E., Persley, D.M. and Hall, B.H. 2010. First report of Tomato torrado virus on tomato from Australia. Plant Disease 94(4): 486-486.

Gibbs, A., and MacKenzie, A. 1997. A primer pair for amplifying part of the genome of all Potyvirus by RT-PCR. Journal of Virological Methods 63(1-2): 9-16.

Goodman, R.N., Kiraly, Z., and Zaitlin, M. 1967. The Biochemistry and Physiology of Infectious Plant Disease. In Johnstone, G.R. and Wade, G.C. 1974. Therapy of Virusinfected Plants by Heat Treatment. Some Properties of Tomato aspermy virus and its Inactivation at $36^{\circ} \mathrm{C}$. Aust. J. Bot. 2: 437-50.

Gunaeni, N., Wulandari, A.W., Duriat, A.S., dan Muharam, A. 2011. Insiden penyakit virus tular umbi pada tiga belas varietas bawang merah asal Jawa barat dan Jawa Tengah. J. Hort. 21(2):164-172.

Johnstone, G. R. and Wade, G. C. 1974. Some Properties of Tomato aspermy virus and its Inactivation at $36^{\circ} \mathrm{C}$. Aust. J. Bot. 22: 437-450.

Kurniawan, A. dan Suastika, G. 2013. Deteksi dan Identifikasi Virus pada Umbi Bawang Merah. Jurnal Fitopatologi Indonesia 9(2): 47-52.

Langeveld, S.A., Dore, J.M, Memelink, J., Derks, A.F., van der Vlugt, C.L., Asjes, C.J., and Bol, J.F. 1991. Identification of Potyoiruses using the polymerase chain reaction with degenerate primers. Journal of General Virology 72(7): 1531-1541.

Styer, D.J. and Chin, C.K. 1983. Meristem and Shoot tip culture for propagation, pathogen elimination and germplasm preservation. Hort. Rev. 5: 221-277.

Swari, F.S.P. 2016. Deteksi dan Identifikasi Virus-Virus yang Menginfeksi Bawang Merah di Kabupaten Bantul, Daerah Istimewa Yogyakarta. Tesis: Universitas Gadjah Mada.

Torres, A.C., Fajardo, T.V., Dusi, A.N., Resende, R.O., and Buso, J.A. 2000. Shoot tip culture and thermotherapy in recovering virus free plants of garlic. Hortic. Bras. 18(3): 192-195.

Van Dijk, P. 1993. Survey and characterization of Potyviruses and their strains of Allium spesies. Neth.J. Pl. Path. 99 (Suppl 2): 1-48.

Van Dijk, P. 1994. Virus disease of Allium species and prospect for their control. Acta Hortic. 358: 299- 306.

Voinnet, O. 2001. RNA silencing as a plant immune system against viruses. Trends in Genetics 17(8): 449-459.

Wulandari, A.W. 2016. Deteksi dan Eliminasi Virus pada Umbi Bawang Merah. Tesis: Institut Pertanian Bogor. 